\title{
ALAT PENJERNIH AIR YANG DIINTEGRASIKAN DENGAN POMPA AIR TENAGA SURYA
}

\author{
Susilawati ${ }^{1)}$, Tulus Ikhsan Nasution ${ }^{2)}$, Nasruddin $\mathrm{MN}^{3)}$ \\ ${ }^{1)}$ Departemen Fisika, Fakultas Matematika dan Ilmu Pengetahuan Alam, Universitas Sumatera Utara \\ Email: susilawati@usu.ac.id \\ ${ }^{2)}$ Departemen Fisika, Fakultas Matematika dan Ilmu Pengetahuan Alam, Universitas Sumatera Utara \\ Email: tulusikhsan@usu.ac.id \\ ${ }^{3)}$ Departemen Fisika, Fakultas Matematika dan Ilmu Pengetahuan Alam, Universitas Sumatera Utara \\ Email: nasnoer1955@gmail.com
}

\begin{abstract}
Abstrak
Mesjid Sunnah Alhidayah dan Yayasan Al Mujahidah Sumatera Utara merupakan salah satu rumah ibadah dan sekolah yang terletak di kelurahan Sari Rejo Kecamatan Medan Polonia yang belum mendapatkan pasokan air bersih dari PDAM Tirtanadi. Masjid Sunnah Alhidayah dan sekolah yayasan Al Mujahidah menggunakan sumur bor untuk mendapatkan pasokan air yang digunakan untuk kebutuhan sehari hari. Masalahnya kondisi air yang diperoleh dari sumur bor berwarna kekuningan, keruh, dan berbau. Warna air sumur yang kekuningan, keruh dan berbau ini menjadi tak layak untuk digunakan apalagi untuk dikonsumsi, tetapi tetap saja warga menggunakan air sumur tersebut untuk keperluan ibadah (mandi dan berwudhu) tanpa melalui proses pengolahan atau penyaringan sama sekali. Implementasi ilmu pengetahuan teknologi di Mesjid Sunnah Alhidayah dan Yayasan Al Mujahidah yang akan dilakukan berupa teknologi alat penjernih air yang diintegrasikan dengan pompa air tenaga surya. alat penjernih air yang diintegrasikan dengan pompa air tenaga surya memiliki keunggulan tidak menggunakan bahan kimia karena hanya menggunakan filter berbasis karbon aktif, pasir zeolit, dan pasir manganese greensand, mengontrol air masuk dan air keluar secara otomatis, filter mudah dibersihkan, menggunakan tenaga surya sehingga ramah lingkungan dan menghemat biaya pembayaran listrik PLN. Implementasi ini dilakukan untuk mengatasi masalah yang sedang dihadapi oleh masyarakat di Kelurahan Sari Rejo umumnya dan mesjid Sunnah Alhidayah serta Yayasan Al Mujahidah khususnya dalam proses penjernihan air, sehingga air dari sumur bor menjadi layak untuk digunakan bahkan untuk dikonsumsi.
\end{abstract}

Kata Kunci : Alat Penjernih Air, Panel Surya, dan Air Bersih.

\section{PENDAHULUAN}

\subsection{Latar Belakang}

Sari Rejo merupakan salah satu kelurahan yang berada di Kecamatan Medan Polonia, Kota Medan, Propinsi Sumatera Utara. Di Kecamatan Medan Polonia, Kelurahan Sari Rejo merupakan Kelurahan yang paling padat penduduk. Pasokan air bersih di Kelurahan Sari Rejo memang sudah tersedia dari PDAM Tirtanadi tetapi tidak menjangkau ke semua rumah rumah penduduk, rumah ibadah, dan sekolah, khususnya yang lokasinya masuk ke dalam gang. Yang mendapat pasokan air dari PDAM Tirtanadi adalah yang posisi rumahnya berada di pinggir jalan besar. Salah satu rumah ibadah dan sekolah yang tidak mendapat pasokan air bersih dari PDAM Tirtanadi adalah Masjid Sunnah Alhidayah dan Sekolah Yayasan Al Mujahidah Sumatera Utara.

Masjid Sunnah Alhidayah dan sekolah yayasan Al Mujahidah menggunakan sumur bor untuk mendapatkan pasokan air. Masalahnya kondisi air yang diperoleh dari sumur bor berwarna kekuningan, keruh, dan berbau. Air sumur yang berwarna kekuningan biasanya disebabkan oleh adanya kandungan zat besi yang tinggi di dalam air. Karena dulunya kelurahan sari rejo ini merupakan daerah rawa. Sedangkan 
air sumur menjadi berbau karena disebabkan oleh adanya bakteri yang berkembang biak dalam air sumur. Warna air sumur yang kekuningan, keruh dan berbau ini menjadi tak layak untuk digunakan apalagi untuk dikonsumsi, tetapi tetap saja warga menggunakan air sumur tersebut untuk keperluan ibadah (mandi dan berwudhu) tanpa melalui proses pengolahan atau penyaringan sama sekali.

\subsection{Rumusan Masalah}

Permasalahan mitra yang menjadi prioritas dalam pengabdian ini adalah:

1) Air Sumur Bor yang ada di Masjid Sunah Al Hidayah dan Yayasan Al Mujahidah merupakan satu satunya sumber air yang digunakan untuk keperluan ibadah (mandi dan berwudhu).

2) Kondisi air sumur bor di Masjid Sunnah Al Hidayah dan yayasan Al Mujahidah yang berwarna kekuningan, keruh, dan berbau.

\subsection{Tujuan Kegiatan}

Tujuan dari kegiatan Pengabdian kepada masyarakat ini adalah menyediakan alat penjernih air yang diintegrasikan dengan pompa air tenaga surya. Penerapan teknologi alat penjernih air yang dintegrasikan dengan pompa air tenaga surya memiliki keunggulan tidak menggunakan bahan kimia karena hanya menggunakan filter berbasis karbon aktif, pasir zeolit, Pasir ferrolite, pasir manganese greensand, dan pasir silika, mengontrol air masuk dan air keluar secara otomatis, filter mudah dibersihkan, tanpa menggunakan energi listrik sehingga sekaligus dapat menghemat pemakaian daya listrik.

\subsection{Manfaat dan Luaran}

Kegiatan ini dapat membantu kelompok masyarakat dalam hal ini mitra yang akan memanfaatkan alat Penjernih air yang telah dibuat. Luaran dari kegiatan ini berupa produk alat penjernih air yang diintegrasikan dengan pompa air tenaga surya, dan Draft
Artikel Ilmiah. Dengan adanya kegiataan ini diharapkan dapat membantu masyarakat dalam proses penjernihan air. Sehingga air dari sumur bor yang digunakan menjadi layak untuk digunakan bahkan untuk dikonsumsi.

\section{METODE PELAKSANAAN}

Metode-metode yang akan dilakukan adalah berupa peninjauan lokasi, pembuatan alat penjernih air, pengujian alat di lokasi mitra, pelatihan penggunaan alat serta evaluasi dan monitoring. Secara rinci Metode Pelaksanaan Kegiatan Pengabdian ini adalah:

a. Peninjauan lokasi: Pada kegiatan survey awal yang dilakukan, pengusul melakukan diskusi dengan Ketua Badan Kenaziran Masjid Sunah Al Hidayah di Kelurahan Sari Rejo. Pengusul memaparkan bagaimana cara mengatasi masalah air sumur yang berwarna kekuningan dan berbau serta alat apa yang akan diberikan untuk membantu masyarakat dalam hal penjernihan air sumur.

b. Observasi: Dilakukan dengan mengambil sampel air baku dari lokasi yang kemudian diuji tingkat kualitas airnya di Laboratorium. Parameter yang diuji antara lain Rasa, Bau, Warna, kekeruhan, pH, Daya Hantar Listrik, dan kandungan beberapa logam seperti $\mathrm{Fe}$, Mn, dan logam logam lainnya.

c. Analisa hasil uji laboratorium : Dari analisa hasil uji laboratorium diharapkan teknologi yang diterapkan ini dapat mengatasi masalah tersebut. hasil uji laboratorium digunakan sebagai referensi agar tidak terjadinya kekeliruan dalam penerapan teknologi.

d. Pembuatan alat penjernih air : alat penjernih air yang diintegrasikan dengan pompa air tenaga surya yang memiliki keunggulan tidak menggunakan bahan kimia karena hanya menggunakan filter berbasis karbon aktif, pasir zeolit, Pasir ferrolite, pasir manganese greensand, dan pasir silika, mengontrol air masuk dan air keluar secara otomatis, filter mudah dibersihkan, menggunakan tenaga surya sehingga ramah lingkungan dan 
menghemat biaya pembayaran listrik PLN.

e. Pengujian alat di lokasi mitra : Pemasangan alat penjernih air di lokasi mitra.

f. Pelatihan penggunaan alat : Melakukan pelatihan, untuk memberikan penjelasan mengenai perinsip kerja, pengoperasian, dan pemeliharaan alat kepada warga di lokasi mitra.

g. Evaluasi dan Monitoring

\section{HASIL DAN PEMBAHASAN}

Langkah awal yang dilakukan dalam kegiataan ini adalah survey awal dan observasi. Hasil survey dapat dilihat pada Gambar 1.

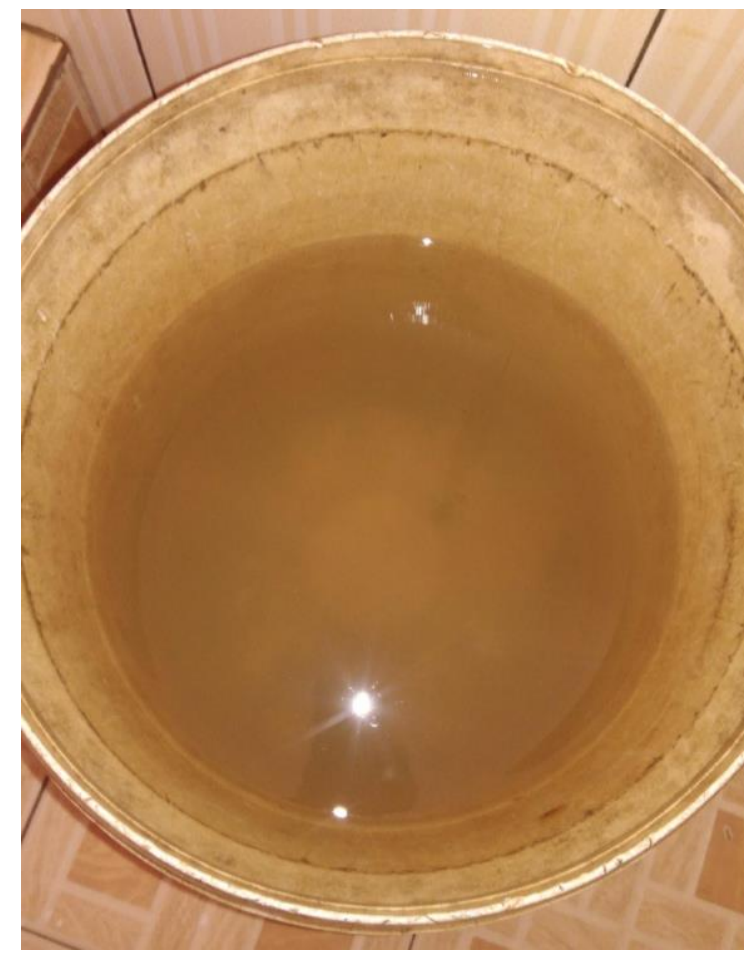

\section{Gambar 1. Air sumur dilokasi mitra yang berwarna kuning, keruh dan berbau.}

Survey awal dan observasi ini dilakukan untuk mengetahui kondisi air sumur yang akan dijernihkan. Kemudian menentukan bahan bahan filter yang akan digunakan untuk menjernihkan air sesuai dengan kondisi air. bahan filter yang akan digunakan adalah Karbon Aktif atau Arang Aktif Tempurung Kelapa (KA), dan Manganese Greensand (MG). Gambar 2 adalah bahan filter Karbon Aktif Tempurung Kelapa dan Manganese Greensand. Karbon aktif diharapkan akan menghilangkan warna kekuningan dan bau yang diakibatkan oleh kandunganlogam Fe dan Mn. Sedangkan Manganese Greensand diharapkan akan menyerap semua kontaminan yang ada dalam air sumur sehingga air yang keruh akan menjadi jernih.



Gambar 2. Karbon Aktif Tempurung
Kelapa dan Manganese Greensand.

Sebelum dilakukan proses penjernihan dilokasi mitra terlebih dahulu dilakukan eksperimen skala laboratorium. Sebelum dan sesudah proses penjernihan diuji beberapa parameter yaitu : pH, Daya Hantar Listrik (DHL), Total Padatan Terlarut (TDS) dan salinity. Hasil pengujian sebelum proses penjernihan ditunjukkan pada Tabel 1 , hasil pengujian sesudah penjernihan ditunjukkan pada Tabel 2, dan hasil pengujian sampel air sumur untuk logam Fe dan Mn pada Tabel 3. 
Tabel 1. Hasil Pengujian Sebelum Proses Penjernihan

\begin{tabular}{|c|c|c|c|}
\hline sampel & $\mathrm{pH}$ & $\begin{array}{c}\text { warna } \\
(\mathrm{TCU})\end{array}$ & $\begin{array}{c}\text { Kekeruhan } \\
(\mathrm{NTU})\end{array}$ \\
\hline \multirow{4}{*}{$\begin{array}{c}\text { Air } \\
\text { Sumur }\end{array}$} & 5.3 & 0.6 & 2.51 \\
\cline { 2 - 4 } & $\begin{array}{c}\mathrm{DHL} \\
(\mu \mathrm{s} / \mathrm{cm})\end{array}$ & $\begin{array}{c}\mathrm{TDS} \\
(\mathrm{mg} / \mathrm{l})\end{array}$ & $\begin{array}{c}\text { salinity } \\
(\mathrm{mg} / \mathrm{l})\end{array}$ \\
\cline { 2 - 4 } & 500 & 142 & 315 \\
\hline
\end{tabular}

Tabel 2. Hasil Pengujian Sesudah Proses Penjernihan.

\begin{tabular}{|c|c|c|c|c|c|c|}
\hline $\begin{array}{c}\text { (KA } \\
+ \\
\mathrm{Mg}) \\
(\mathrm{kg})\end{array}$ & $\mathrm{pH}$ & $\begin{array}{c}\text { war } \\
\text { na } \\
\text { (TC } \\
\text { U) }\end{array}$ & $\begin{array}{c}\text { keker } \\
\text { uhan } \\
\text { (NTU } \\
\text { ) }\end{array}$ & $\begin{array}{c}\text { DHL } \\
(\mu \mathrm{s} / \mathrm{c} \\
\mathrm{m})\end{array}$ & $\begin{array}{c}\mathrm{TD} \\
\mathrm{S} \\
(\mathrm{mg} \\
/ \mathrm{l})\end{array}$ & $\begin{array}{c}\text { Sali } \\
\text { nity } \\
(\mathrm{mg} \\
/ \mathrm{l})\end{array}$ \\
\hline $\begin{array}{l}0(5 \\
+0)\end{array}$ & 7.14 & $\begin{array}{c}< \\
0.2\end{array}$ & 1.16 & 262 & 111 & 160 \\
\hline $\begin{array}{r}15 \\
+1) \\
\end{array}$ & 7.51 & $\begin{array}{c}< \\
0.2\end{array}$ & 1.25 & 680 & 95 & 160 \\
\hline $\begin{array}{l}2(5 \\
+2)\end{array}$ & 7.20 & $\begin{array}{c}< \\
0.2\end{array}$ & 1.26 & 354 & 74 & 132 \\
\hline $\begin{array}{r}3(5 \\
+3) \\
\end{array}$ & 7.77 & $\begin{array}{c}< \\
0.2\end{array}$ & 1.25 & 345 & 95 & 158 \\
\hline $\begin{array}{r}4(5 \\
+4) \\
\end{array}$ & 6.64 & $\begin{array}{c}< \\
0.2\end{array}$ & 1.16 & 335 & 95 & 155 \\
\hline $\begin{array}{l}5(5 \\
+5)\end{array}$ & 7.02 & $\begin{array}{c}< \\
0.2\end{array}$ & 1.15 & 289 & 86 & 130 \\
\hline
\end{tabular}

Tabel 3. Hasil Pengujian Sampel Air Sumur Untuk Logam Fe dan Mn

\begin{tabular}{|c|c|c|}
\hline $\begin{array}{c}\text { Sampel }(\mathrm{KA}+\mathrm{Mg}) \\
(\mathrm{kg})\end{array}$ & $\begin{array}{c}\mathrm{Fe} \\
(\mathrm{mg} / \mathrm{l})\end{array}$ & $\begin{array}{c}\mathrm{Mn} \\
(\mathrm{mg} / \mathrm{l})\end{array}$ \\
\hline $00(0+0)$ & 6.05 & $<0.005$ \\
\hline $0(5+0)$ & 0.04 & $<0.005$ \\
\hline $1(5+1)$ & 0.03 & $<0.005$ \\
\hline $2(5+2)$ & 0.02 & $<0.005$ \\
\hline $3(5+3)$ & 0.05 & $<0.005$ \\
\hline $4(5+4)$ & 0.01 & $<0.005$ \\
\hline $5(5+5)$ & 0.04 & $<0.005$ \\
\hline
\end{tabular}

Hasil dari Tabel 1, Tabel 2, dan Tabel 3, digunakan sebagai dasar untuk menentukan Karbon Aktif Tempurung Kelapa dan Manganese Greensand yang akan digunakan untuk penjernihan air di lokasi mitra. Perbandingan yang digunakan untuk
(KA:MG) pada proses penjernihan air sumur adalah $(15 \mathrm{Kg}: 10 \mathrm{Kg})$. Perbandingan ini disesuaikan juga dengan tabung filter yang digunakan. Proses penjernihan air berhasil dilakukan, air yang tadinya berwarna kekuningan dan berbau telah menjadi jernih dan tidak berbau setelah melewati filter

Sistem penyaringan dari filter ke tangki penampungan sudah efektif untuk distribusi air ke kamar mandi dengan banyak keran, tetapi ketika tangki air tidak dibersihkan dan tidak ditutup maka air akan kembali berwarna kuning. untuk mengatasi hal ini yang perlu dilakukan adalah mencuci tangki air minimal seminggu sekali dan menutup tangki penampungan air. Pada tangki penampungan juga telah dipasang radar air yang berfungsi mengontrol air yang masuk ke tangki, jika tangki sudah penuh maka otomatis pompa akan mati. Alat penjernih air yang digunakan dapat dilihat pada Gambar 3 sedangkan panel surya yang diintegrasikan dengan pompa air dapat dilihat pada Gambar 4.

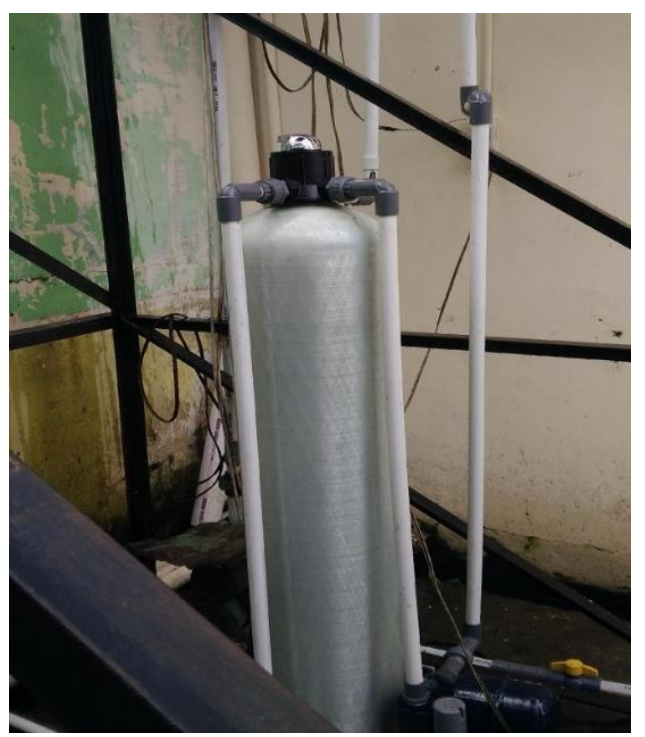

Gambar 3. Alat Penjernih Air 


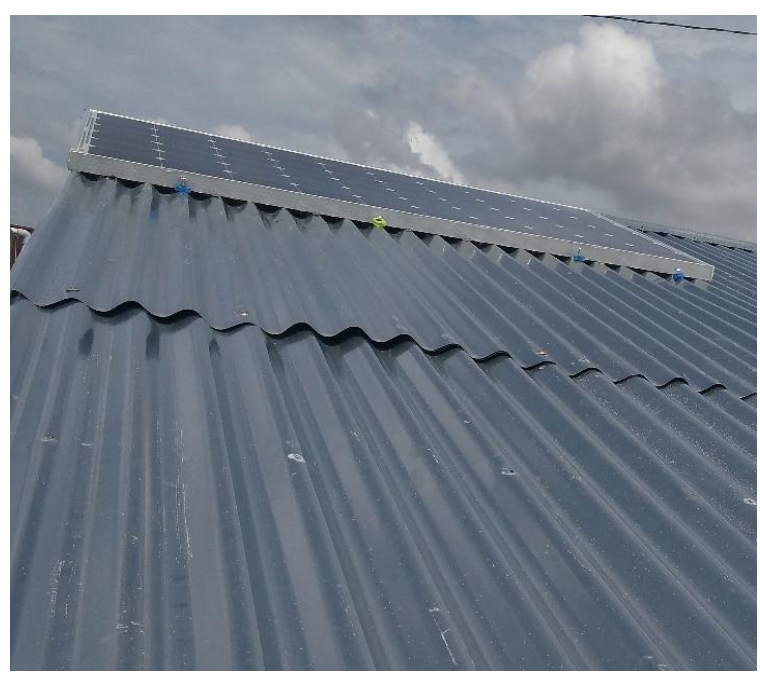

Gambar 4. Panel Surya yang diintegrasikan dengan pompa air

Alat penjernih air yang digunakan pada proses penjernihan diintegrasikan dengan pompa air tenaga surya sudah beroperasi dengan baik. Panel surya yang digunakan untuk pompa air, sudah berjalan dengan normal, hanya akan sangat tergantung dari cuaca atau sinar matahari. Ketika hari cerah maka kebutuhan listrik untuk menghidupkan pompa tercukupi, tetapi sebaliknya jika hari mendung atau hujan maka kebutuhan listrik harus tetap dipasok dari PLN. Pada sistem telah dipasang alat otomatis, ketika panel surya tidak mencukupi pasokan listrik yang dibutuhkan maka otomatis akan dialihkan ke listrik dari PLN. Secara keseluruhan alat penjernih air yang diintegrasikan dengan pompa air tenaga surya dapat dilihat pada Gambar 5.

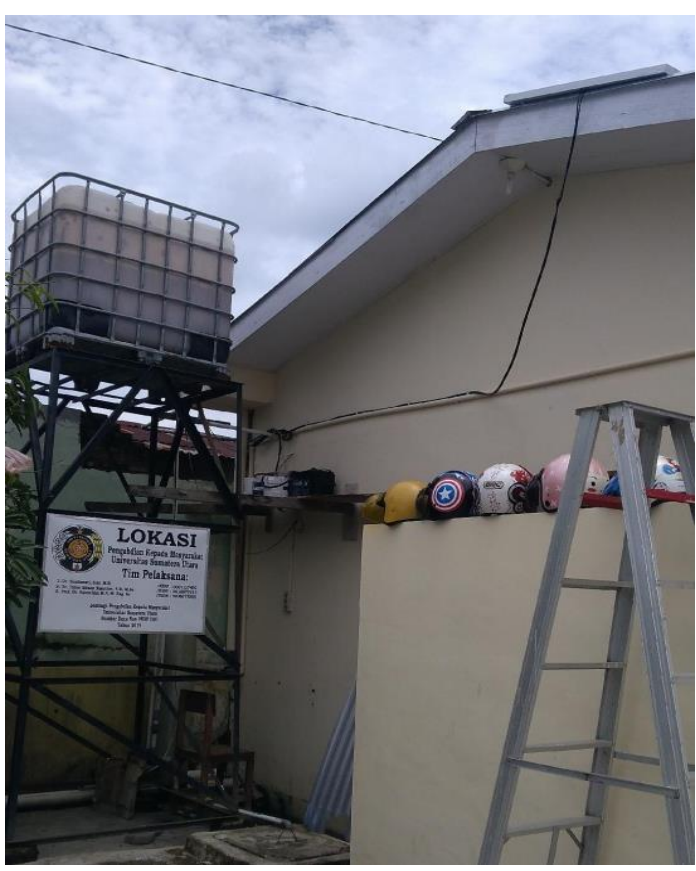

Gambar 5. Alat Penjernih Air Yang Di integrasikan dengan Pompa Air Tenaga Surya.

\section{KESIMPULAN}

Dari kegiatan ini dapat ditarik beberapa kesimpulan:

1. Alat Penjernih Air Yang Terintegrasi Dengan Pompa Air Tenaga Surya memanfaatkan teknologi tepat guna bagi masyarakat.

2. Alat Penjernih Air memiliki keunggulan tidak menggunakan bahan kimia karena hanya menggunakan filter berbasis Karbon Aktif Tempurung Kelapa, dan Pasir Manganese Greensand, mengontrol air masuk dan air keluar secara otomatis, filter mudah dibersihkan.

3. Alat penjernih air ini menggunakan tenaga surya sehingga ramah lingkungan dan menghemat biaya pembayaran listrik PLN.

\section{SARAN}

Alat penjernih air ini diharapkan tidak hanya bisa digunakan untuk menjernihkan air sumur saja. Akan tetapi bisa juga untuk penjernihan air sungai, dan air dengan 
kondisi berwarna kekuningan, keruh dan berbau.

\section{UCAPAN TERIMAKASIH}

Penulis mengucapkan terimakasih kepada LPPM USU melalui dana NON PNBP Universitas Sumatera Utara Program Mono Tahun, Tahun Anggaran 2018 yang telah memberi dukungan finansial terhadap pengabdian kepada masyarakat ini.

\section{DAFTAR PUSTAKA}

Hans K., Khaterine, Jenny M.N.S., Felicia P., Candra W., Handriono, Guntoro R.J., Farand, Billy Y.S., Yana M., 2017, Penyediaan Air Bersih Masyarakat Sekitar Masjid Al-Ikhlas Desa Cukanggenteng, Ciwidey dengan Penyaringan Air Sederhana, Jurnal Pengabdian Kepada Masyarakat, Vol. 3 No. 1 Yogyakarta.

Idaman N., Heru D.W., 1999, Pembuatan Filter Untuk Menghilangkan Zat Besi Dan Mangan di Dalam Air, Badan Pengkajian Dan Penerapan Teknologi Jakarta.

Ingole Nitin W., Dharpal Sachin V., 2012, State of Art Biosorption Technique for Treatment of Heavy Metals Bearing Wastes, International Journal of Advanced Engineering Technology, 3 (2) pp. $143-153$.

Muhammad R.J., Rudiyanto, dan Risdiawan Hartanto, 2013, Portable Alat penjernih Air Dengan Sistem Filtrasi, Jurnal Riset Daerah, Edisi Khusus.

PERMENKES RI No. 32 Tahun 2017 Tentang Standar Baku Mutu Kesehatan Lingkungan dan persyaratan Kesehatan Air.

Peraturan Pemerintah Republik Indonesia no 66 Tahun 2014 tentang Kesehatan Lingkungan.

Rachmat Quddus, 2014, Teknik Pengolahan Air Bersih Dengan Sistem Saringan Pasir Lambat (Down Flow) Yang Bersumber Dari Sungai Musi, Jurnal Teknik Sipil dan Lingkungan, Vol. 2 No. 4.
PERMENKES RI No. 492 / Menkes / PER / IV / 2010 Tentang Persyaratan Kualitas Air Minum.

Rizky Yudi S.U., 2017, Studi Efektifitas Penjernih Air Menggunakan Media Zeolit, Karbon Aktif dan Pasir Silika Untuk Mngurangi Kadar Besi (Fe) Dan Mangan (Mn) Dengan Variasi Sudut Kemiringan Pada Alat Uji Dan penambahan Filter Keramik, Jurnal Ilmiah Teknik Pengairan Konsentrasi Konservasi Sumber Daya Air, Malang. 